\title{
Effect of Foliar Spray with Boron and Copper Sulphate on Productivity of some
} Garlic Cultivars

\author{
${ }^{1}$ Badr L.A., M.H. Mohamed ${ }^{1}$, Mohamed A.A. Abd Ellteif ${ }^{2}$ and T.M. Abd Elmonem ${ }^{1}$ \\ ${ }^{1}$ Horticulture Department, Faculty of Agriculture, Benha University, Egypt. \\ ${ }^{2}$ Horticulture Research Institute, Agricultural Research Center, Giza, Egypt.
}

Received: 19 Nov. 2019 / Accepted 15 Jan. 2020 / Publication date: 15 June 2020

\begin{abstract}
Two field experiments were carried out during the two successive winter seasons of 2017/2018 and 2018/2019 at Experimental Farm of Vegetable Research Institute at Kaha, Horticulture Research Institute, Agriculture Research Center (ARC), to study the effect of cultivars, i.e. Balady, Sids 40 and Egaseed, as well as some foliar spray substances, i.e. Boron at 100 and 200 ppm and Copper Sulphate at 1000 and 2000ppm in addition to the control (spraying with tap water). The experimental treatments were arranged in a split plot design. The foliar spray treatments were carried out four times during the growing season, the first spray was followed after four weeks from planting date and the others were applied each two weeks as intervals between them. The results indicated that the tallest garlic plants that carried the highest number of leaves as well as the heaviest fresh and dry weight of whole plant and its different organs were associated with plants of Balady cultivar. These results were completely similar in the two seasons. However, the lowest values were obtained in case of cv. Sids 40 . The highest values in all vegetative growth measured traits were recorded in case of using $\mathrm{CuSO}_{4}$ at 2000ppm or boron at 200ppm during the two seasons of study. Balady cultivar and sprayed with $\mathrm{CuSO}_{4}$ at $2000 \mathrm{ppm}$ resulted in the best values of plant growth parameters. Egaseed cultivar recorded the highest values in phosphorus, potassium, carbohydrates and copper content. Meanwhile, cv. Balady gave the highest content of nitrogen, sulphur and boron. On the other hand, cv. Sids 40 gave the lowest values of all chemical constituents of plant foliage. Moreover, all foliar spray treatments significantly increased N, $\mathrm{P}, \mathrm{K}$, carbohydrates and, $\mathrm{S}$ percentages, and $\mathrm{B}$ and $\mathrm{Cu}(\mathrm{ppm})$ compared to the control treatment (spraying with tap water). Spraying the plants with $\mathrm{CuSO}_{4}$ at 2000ppm recorded the highest increments in all assayed nutrient content. Egaseed cultivar plants foliar sprayed with $\mathrm{CuSO}_{4}$ at $2000 \mathrm{ppm}$ produced the highest significant values of nitrogen as well as phosphorus, potassium, carbohydrates and copper. Whereas, the highest significant values for sulphur and boron contents were gained with Balady cultivar sprayed with Boron at $200 \mathrm{ppm}$. However, plants of Egaseed cultivar recorded the highest values in all studied yield parameters except number of cloves which found in Balady cultivar. The highest total produced bulb yield was obtained as a result of spraying Egaseed cv. plants with $\mathrm{CuSO}_{4}$ at $2000 \mathrm{ppm}$ during the two season of growth.
\end{abstract}

Keywords: Garlic, Cultivars, Boron, Sulphur, Vegetative growth, Chemical composition, Yield, Bulb quality

\section{Introduction}

Garlic (Allium sativum $\mathrm{L}$ ) is considered as one of the most important bulb vegetable crops belong to Alliaceae family followed to onion (Allium cepa L.) in Egypt; it has been generally cultivated for both local consumption and exportation to different countries. Egypt ranks the fourth leading country in the world in garlic production (244.626 MT) after China, India and South Korea., according to Central Administration for Agricultural Economics and Statistics, Ministry of Agriculture, Egypt 2016. total area cultivated with garlic during 2016 reached about 29961 feddans, with the total productivity of 276556 tons with an average yield of 9.2 tons per feddan

Garlic is the most popular food ingredient widely used all over the world. During the last few decades, garlic has received tremendous attention for their wide range of therapeutic properties and great health benefits. Garlic has possessed antibacterial, antifungal, antiparasitic, antiviral, antioxidant, anticholesteremic, anti-cancerous, and vasodilator characteristics (Lenkova et al., 2018).

Moreover, Garlic is commonly used as a spice or in the medicinal properties uses. Therefore, increasing garlic yield and improving bulb quality are essential aims for both growers and consumers, Corresponding Author: Badr L.A., Horticulture department, Faculty of Agriculture, Benha University, Egypt. 
but it usually depends on many factors especially that influence the plant growth throughout the growth period. The composition of a garlic bulb varies greatly depending on cultivar, agronomic practices, climate, soil fertility, and postharvest storage conditions that determine the quality and intensity flavor as well as nutritional and nutraceutical values of the crop. Among garlic cultivars and clones, the variation is great and differences can be found in all or some garlic characteristics, i.e. plant height, plant fresh weight, and yield.

Micronutrients are needed for plants in small quantities; however, their deficiencies cause great disturbances in the physiological, cellular functions and metabolite processes in the plant. Also, they work as co-enzymes for a large number of enzymes. In addition, they play an essential role in, and are highly required for better plant growth and yield with improved quality.

The micronutrients play an important role in the growth and yield of garlic. The advantage of micronutrients is not inadequate exclusively to the replacement of the micronutrient itself but in accumulation micronutrient acts as catalyst in the uptake and use of certain macronutrients. Foliar application of micronutrients during crop growth was successfully used for correcting the deficits and improving the mineral status of plants as well as increasing the crop yield and quality.

Sulphur is an essential plant nutrient and its role in balanced fertilization and consequently in crop production is being increasingly appreciated. Sulphur is the fourth major plant nutrient after nitrogen, phosphorus and potassium. It is essential for synthesis of amino acid like cysteine and methionine a component of vitamin A and activates certain enzyme system in plants (Zhou et al., 2018). Continuous removal of sulphur from soil by plant led to widespread to deficiency (decreases) and affected soil sulphur budget all over the world (Choudhary et al., 2014).

Sulphur application to garlic plants enhances the uptake of NPK and Ca by the crop as well as increases in yield of garlic. The balance use of all the nutrients along with sulphur is necessary for good yields and quality in garlic (Babaleshwar et al., 2017).

Copper is a redox - active transition element that has roles in photosynthesis, respiration, $\mathrm{C}$ and $\mathrm{N}$ metabolism, and protection against oxidative stress. Some studies suggest that $\mathrm{Cu}$ may play a part in the synthesis or the stability of chlorophyll and other plant pigments. Most of the function of $\mathrm{Cu}$ are based on enzymatically bound $\mathrm{Cu}$ which catalysis redox reaction (Rizk et al., 2014).

Boron is one of the most important micro-nutrients, although it is required in very small quantity and regulates the carbohydrate metabolism and water relation in plant growth (Manna et al., 2014) Boron deficiency in fresh market fruits is often not documented by growers. Boron deficiency, however, is widespread and can serious yield diminution and irregular ripening of fruit. Boron becomes less accessible to plants as soil $\mathrm{pH}$ increases. Therefore, the practice of applying lime to improve the uptake of other nutrients can cause B deficiency (Zhang et al., 2012).

Therefore, the objectives of this study were to determine cultivars to maximize yield and quality of garlic and to evaluate the effect of foliar application of sulphur, copper and boron on garlic yield under the Qaulibia region.

\section{Materials and Methods}

Two field experiments were carried out during the two successive winter seasons of 2017/2018 and 2018/2019 in the Experimental Farm at Kaha, Vegetable Research Farm (El-Kaluobia Governorate), Horticulture Research Institute, Agriculture Research Center (ARC), Egypt. to study the effect of some garlic (Allium sativum) varieties (Balady, Sids and Egaseed) and foliar spray with boron and copper sulphate on vegetative growth, chemical composition, bulb yield and its components and bulb quality. The soil of the experimental farm was clay loam in texture with $\mathrm{pH}$ 7.9. Soil mechanical and chemical analysis. These rates indicate the average of two years are shown in Table (1).

The study included 15 treatments, which were the combination between three cultivars and five foliar spray treatments as follows:

\section{A: - The tested cultivars:}

Three garlic cultivars used in this study were recognized as the most common commercial cultivars in Egypt. Garlic cloves were obtained from Hort. Res. Inst., potato Res. Dep., Ministry of Agriculture, Dokki, Giza, Egypt as follows: 
Table 1: Soil mechanical and chemical analysis of the used soil

\begin{tabular}{|c|c|c|c|c|c|}
\hline \multirow{2}{*}{\multicolumn{2}{|c|}{ Mechanical analysis }} & \multicolumn{4}{|c|}{ Chemical analysis } \\
\hline & & \multicolumn{2}{|c|}{ Cations meq/l } & \multicolumn{2}{|c|}{ Anions meq/l } \\
\hline Coarse sand & $8.25 \%$ & $\mathbf{C a}^{++}$ & 9.65 & $\mathrm{CO}_{3}^{--}$ & Zero \\
\hline Fine sand & $16.15 \%$ & $\mathbf{M g}^{++}$ & 3.16 & $\mathrm{HCO}_{3}^{-}$ & 5.38 \\
\hline Silt & $24.60 \%$ & $\mathrm{Na}^{+}$ & 6.53 & $\mathrm{Cl}^{-}$ & 5.93 \\
\hline Clay & $51 \%$ & $\mathbf{K}^{+}$ & 1.16 & $\mathrm{SO}_{4}^{--}$ & 9.19 \\
\hline \multicolumn{6}{|c|}{ Texture class clay loam } \\
\hline Soil pH & 7.9 & Available N & $22.5 \mathrm{mg} / \mathrm{kg}$ & & \\
\hline E.C, $\mathrm{dS} / \mathrm{m}$ & 2.16 & Available $\mathbf{P}$ & $9.1 \mathrm{mg} / \mathrm{kg}$ & & \\
\hline Organic matter & $3.1 \%$ & Available K & $120 \mathrm{mg} / \mathrm{kg}$ & & \\
\hline
\end{tabular}

\section{Local Balady Egyptian:}

It's a local cultivar grown in Egypt for its strong aroma the mature cloves have white covering scale, high number of cloves per bulb and small cloves size.

\section{1- Sids 40 (Chinese):}

It's a commercial cultivar grown in Egypt has big sized cloves, easy peeled, low number of cloves per bulb and its mature cloves have colored skin. It's a selected in Clone from Sids Horticulture Research Station, Agricultural Research Center, Egypt.

\section{2- Egaseed:}

It's a promising local cultivar grown in Egypt has big sized cloves, low number of cloves per bulb and mature cloves have colored skin. Genotype produced by the Egyptian Agricultural Company for seed production, Egypt.

\section{B: - Foliar spray treatments \\ 1- Boric acid at $100 \mathrm{ppm}$ \\ 2- Boric acid at $200 \mathrm{ppm}$ \\ 3- $\mathrm{CuSO}_{4}$ at $1000 \mathrm{ppm}$. \\ 4- $\mathrm{CuSO}_{4}$ at 2000ppm \\ 5- Control (spray with tap water)}

A split plot design with three replicates was adopted, where the cultivars were distributed in the main plots and the foliar spray treatments were randomly distributed in the sub-plots. The cloves of garlic were planted at $7 \mathrm{~cm}$ apart on two sides of ridge, $70 \mathrm{~cm}$ in width. Each experimental plot included four rows with 4 meters in length and $70 \mathrm{~cm}$ width with an area of about $11.2 \mathrm{~m}^{2}$, a guard ridge was left between each adjacent plot to prevent fertilization diffusion from any plot to adjacent one as well as foliar spray. Garlic cloves were sown in $25^{\text {th }}$ and $10^{\text {th }}$ of September in the first and second season respectively. Garlic cloves were selected for uniformity in shape and size.

Boric acid solution was dissolved at 0.1 or $0.2 \mathrm{~g}$ of boric acid in liter water. Copper sulphate was prepared by dissolving 1000 an $2000 \mathrm{ppm}$. All foliar applications were sprayed 4 times, starting after 30 days from planting with 15 days as intervals between them.

The normal agricultural practices i.e. irrigation, fertilization, weeds control, as well as diseases and pest control were followed according to the recommendations of the Egyptian Ministry of Agriculture.

\section{Recorded data were as follows:}

\section{Vegetative growth characteristics.(90 days from planting)}

Five plants were randomly chosen from each experimental plot at 90 days from planting date to determine the following parameters.

Plant height $(\mathrm{cm})$, number of leaves/plant, shoot diameter $(\mathrm{cm})$, fresh and weight/ plant $(\mathrm{g})$

\section{Chemical composition of plant foliage:}

Total nitrogen, phosphorus, potassium and carbohydrates content were determined in the digested dry matter of plant foliage according to methods described by Pregl (1945), John (1970), 
Brown and Lilleland (1946) respectively and Herbert et al., (1970) meanwhile copper, sulphur and boron were determined according to A. O.A. C. (1990).

\section{Bulbs yield and its components: (180days from planting).}

A random sample of 10 plants was taken from each plot at full ripe stage (180 days from planting date) in both seasons of study for measuring the following characters:

Plant weight (g), number of cloves/bulb, average head weight (g) an total yield (ton/fed).

\section{Bulb quality:}

A random sample of 10 bulbs at full ripe stage from each experimental plot was taken to determine the following properties.

Average bulb length, diameter $(\mathrm{cm})$ and cloves weight $(\mathrm{g})$ as well as bulbing ratio: it was measured in garlic plants by using the following formula as described by Mann (1952).

$$
\text { Bulbing ratio }=\frac{\text { Neck diameter }}{\text { Bulb diameter }}
$$

\section{Statistical analysis}

All obtained data were subjected to the statistical analysis and means were compared according to LSD at 5\% level test described by Gomez and Gomez (1984).

\section{Result and Discussion}

\section{1- Vegetative growth characteristics:-}

Data in Table (2) show clearly that various used garlic the cultivars significantly affected plant growth measurements, during both experimental seasons. These findings were true for all plants growth characters, i.e., plant height, number of leaves per plant, shoot diameter, fresh and dry weight of garlic plant foliage. Whereas, the tallest garlic plants that possessed the highest stem diameter as well as the heaviest fresh and dry weight of whole plant and its different organs, were associated with plants of using Balady cultivar, followed by Egaseed cultivar. Meanwhile, plants of Egaseed cultivar recorded the highest number of leaves per plant followed by Sids 40 cultivar in the first season and Balady cultivar in the second one. These results were completely similar in two seasons. However, the lowest values were obtained in case of $\mathrm{cv}$. Sids 40 . This may be due to the genetic background of each cultivar and the variations among three genotypes. These results are in agreement with those reported by Akbari et al.(2017) and Hegazy et al. (2019). Moreover, Akbari et al. (2017) mentioned that significant differences among all studied local cultivars and ecotypes of Egyptian garlic were observed for vegetative growth .In this respect Borg El-Arab landrace was superior in vegetative growth as plant height $(\mathrm{cm})$, leaves no./plant, leaf length $(\mathrm{cm})$, leaf width $(\mathrm{mm})$, plant fresh weight $(\mathrm{g})$ and foliage fresh weight (g) compared with purple bulbs landraces like Egaseed and Sids-40. Whereas, Zaki et al. (2014) indicated that Balady cultivar recorded the longest plants, however, Sids- 40 plants showed the heaviest fresh and dry shoot weight.

The response of garlic plants to boron and copper sulphate as compared to that not treated during the two experimental seasons of 2017/2018 and 2018/2019 are presented in Table (2). Generally, application of the two active materials of plants growth substances resulted in more vigorous plants compared to the control plants (sprayed with tap water). Moreover, statistical analysis of the obtained data reveal that, the differences within various treatments respecting to their effects on plant growth parameter are enough to reach the $5 \%$ level of significance. These were true in both seasons except for shoot diameter of plants, Whereas, within the two plant growth active substances used, the recorded data showed that, foliar application of boron at 100 and 200ppm and copper sulphate at 1 and $2 \mathrm{~g} / 1$ starting 30 days after planting and every 2 weeks as intervals gained the most vigor plant as expressed by height of plant, number of leaves and shoot diameter, fresh and dry weight of whole plant and its different organs. In this respect, the highest values in all measured traits were recorded in case of using $\mathrm{CuSo}_{4}$ at $2000 \mathrm{ppm}$ followed by $\mathrm{CuSo}_{4}$ at $1000 \mathrm{ppm}$ and boron at $200 \mathrm{ppm}$ during the two seasons of study; Obtained results are in accordance with those reported by Choudhary et al., (2014) and Zhou et al., (2018). The positive influence of foliar application of micro-nutrients on crop growth may be due to the improved ability of the crop to absorb nutrients, improved photosynthesis process and consequently they play vital role in various bio- chemical processes (Zhang et al., 2012). Similar results 
were obtained by Manna et al. (2014) and Rizk et al.(2014). This might be due to maximum vegetative growth which enhanced maximum photosynthesis and accumulation of more dry matter in plants.

Table 2: Effect of cultivars, foliar spray with boron or copper sulphate as well as their interactions on vegetative growth of garlic plants ( 90 days from planting) during two seasons of study.

\begin{tabular}{|c|c|c|c|c|c|c|c|c|c|c|c|}
\hline \multicolumn{2}{|c|}{ Treatment } & \multicolumn{5}{|c|}{$2017 / 2018$} & \multicolumn{5}{|c|}{$2018 / 2019$} \\
\hline Cultivars & $\begin{array}{c}\text { Foliar } \\
\text { spray }\end{array}$ & $\begin{array}{c}\text { Plant } \\
\text { height } \\
(\mathrm{cm})\end{array}$ & $\begin{array}{c}\text { No. } \\
\text { of } \\
\text { leaves }\end{array}$ & $\begin{array}{c}\text { Shoot } \\
\text { diameter } \\
(\mathrm{cm})\end{array}$ & $\begin{array}{c}\text { Plant } \\
\text { Fresh } \\
\text { weight } \\
\text { (g) }\end{array}$ & $\begin{array}{l}\text { Plant } \\
\text { Dry } \\
\text { weight } \\
\text { (g) }\end{array}$ & $\begin{array}{c}\text { Plant } \\
\text { height } \\
(\mathrm{cm})\end{array}$ & $\begin{array}{l}\text { No of } \\
\text { leaves }\end{array}$ & $\begin{array}{c}\text { Shoot } \\
\text { diameter } \\
(\mathrm{cm})\end{array}$ & $\begin{array}{c}\text { Plant } \\
\text { Fresh } \\
\text { weight } \\
\text { (g) }\end{array}$ & $\begin{array}{c}\text { Plant } \\
\text { Dry } \\
\text { weight } \\
\text { (g) }\end{array}$ \\
\hline Balady & & 88.24 & 9.62 & 1.84 & $\frac{(b)}{116.20}$ & 27.29 & 84.60 & 10.23 & 2.16 & $\frac{18}{184.90}$ & 26.02 \\
\hline Sids40 & & 51.20 & 9.86 & 1.16 & 59.74 & 16.98 & 55.36 & 9.76 & 1.43 & 84.73 & 9.90 \\
\hline Egaseed & & 68.37 & 10.90 & 1.55 & 105.52 & 30.14 & 53.63 & 10.68 & 1.93 & 147.76 & 18.69 \\
\hline LSD at $5 \%$ & & 5.19 & 0.75 & 0.30 & 22.74 & 2.28 & 5.03 & 0.37 & 0.17 & 30.12 & 4.63 \\
\hline \multirow[b]{6}{*}{ LSD at $5 \%$} & B 100ppm & 66.96 & 9.97 & 1.50 & 91.26 & 23.31 & 64.23 & 10.00 & 1.72 & 125.00 & 15.73 \\
\hline & B 200ppm & 70.56 & 10.00 & 1.54 & 93.50 & 23.80 & 64.94 & 10.27 & 1.80 & 139.55 & 17.81 \\
\hline & $\mathrm{CuSO}_{4} 1000 \mathrm{ppm}$ & 70.06 & 10.34 & 1.55 & 97.94 & 25.40 & 68.72 & 10.55 & 1.92 & 152.83 & 19.20 \\
\hline & $\mathrm{CuSO}_{4} 2000 \mathrm{ppm}$ & 71.88 & 10.41 & 1.60 & 103.31 & 29.52 & 68.22 & 10.77 & 2.06 & 162.05 & 23.16 \\
\hline & Control & 66.87 & 9.92 & 1.40 & 83.11 & 22.01 & 56.54 & 9.53 & 1.68 & 116.22 & 15.12 \\
\hline & & 4.13 & 0.39 & 0.15 & 15.83 & 2.03 & 4.77 & 0.46 & 0.35 & 29.08 & 3.87 \\
\hline \multirow{5}{*}{ Balady } & B 100ppm & 86.86 & 9.43 & 1.87 & 109.43 & 25.10 & 58.33 & 10.00 & 2.03 & 173.00 & 21.70 \\
\hline & B 200ppm & 90.30 & 9.43 & 1.86 & 114.43 & 25.40 & 83.50 & 10.50 & 2.06 & 186.66 & 25.20 \\
\hline & $\mathrm{CuSO}_{4} 1000 \mathrm{ppm}$ & 88.06 & 9.96 & 1.86 & 123.33 & 28.83 & 83.66 & 10.50 & 2.23 & 194.66 & 26.93 \\
\hline & $\mathrm{CuSO}_{4} 2000 \mathrm{ppm}$ & 90.76 & 9.96 & 1.93 & 127.20 & 35.73 & 88.83 & 10.50 & 2.33 & 199.16 & 35.50 \\
\hline & Control & 85.20 & 9.30 & 1.70 & 106.63 & 21.40 & 81.66 & 9.66 & 2.13 & 171.00 & 20.76 \\
\hline \multirow{5}{*}{ Sids40 } & B 100ppm & 50.53 & 9.73 & 1.16 & 59.96 & 16.40 & 53.00 & 9.33 & 1.23 & 66.16 & 9.33 \\
\hline & B 200ppm & 51.40 & 9.83 & 1.16 & 60.53 & 16.50 & 55.83 & 9.66 & 1.36 & 76.83 & 9.50 \\
\hline & $\mathrm{CuSO}_{4} 1000 \mathrm{ppm}$ & 51.93 & 9.96 & 1.21 & 60.53 & 17.40 & 57.00 & 10.33 & 1.55 & 103.66 & 10.10 \\
\hline & $\mathrm{CuSO}_{4} 2000 p p m$ & 52.50 & 10.06 & 1.25 & 68.30 & 18.43 & 59.00 & 10.66 & 1.80 & 117.66 & 11.33 \\
\hline & Control & 49.66 & 9.73 & 1.03 & 49.40 & 16.20 & 52.00 & 8.83 & 1.20 & 59.33 & 9.26 \\
\hline \multirow{5}{*}{ Egaseed } & B 100ppm & 65.16 & 10.76 & 1.46 & 104.40 & 28.43 & 54.36 & 10.66 & 1.90 & 135.83 & 16.16 \\
\hline & B 200ppm & 70.00 & 10.73 & 1.60 & 105.53 & 29.50 & 55.50 & 10.66 & 1.96 & 155.16 & 18.73 \\
\hline & $\mathrm{CuSO}_{4} 1000 \mathrm{ppm}$ & 70.20 & 11.10 & 1.60 & 109.96 & 29.96 & 65.50 & 10.83 & 2.00 & 160.16 & 20.56 \\
\hline & $\mathrm{CuSO}_{4} 2000 \mathrm{ppm}$ & 72.40 & 11.20 & 1.63 & 114.43 & 34.40 & 56.83 & 11.16 & 2.06 & 169.33 & 22.66 \\
\hline & Control & 64.10 & 10.73 & 1.46 & 93.30 & 28.43 & 35.96 & 10.10 & 1.72 & 118.33 & 15.33 \\
\hline LSD at $5 \%$ & & 7.16 & 1.20 & 0.26 & 27.43 & 10.45 & 8.46 & 1.15 & 0.62 & 28.37 & 7.38 \\
\hline
\end{tabular}

The interaction between the two factors (cultivars and foliar spraying with some growth active substances) as affected growth criteria's of garlic plants during the two seasons of 2017/2018 and 2018/2019 are presented in Table (2). Generally, significant effects were found regarding the interaction treatments on all measurements of plant growth. But generally it could be extracted that using Balady cultivar for planting and foliar spraying by $\mathrm{CuSO}_{4}$ at $2000 \mathrm{ppm}$ resulted in the best values of plant growth parameters. Moreover, foliar application of two active substances under the three used cultivars caused an enhancement in plant growth of garlic compared to the control treatment.

\section{Chemical constituents of plant foliage:}

With regard to the effect of cultivars, data in Tables ( 3 and 4) show clearly that there were significant differences in chemical composition among the studied garlic cultivars during both seasons of study. In this respect, plant of Egaseed cultivar recorded the highest values in, phosphorus, potassium, carbohydrates and copper content. Meanwhile, cv. Balady gave the highest content in nitrogen, sulphur and boron content. On the other hand, cv. Sids 40 gave the lowest values of all studied chemical constituents of plant foliage. Obtained results were true during both seasons of study. Such differences in chemical constituents among the studied cultivars may be attributed to the potential of genetic differences among such genotypes. Obtained results are in accordance with those reported by Akbari et al., (2017) and Hegazy et al., (2019). In this regard, Ahmed (2012) indicated that nitrogen, phosphorus and potassium content (\%) were high in bulbs of Chinese cultivar, but nitrogen and phosphorus contents were high in leaves of Balady cultivar.

The effect of foliar substances, i.e., boric acid and copper sulphate on total nitrogen, phosphorus, potassium, carbohydrates, sulphur, boron and copper content are presented in Tables ( 3 and 4 ). 
Table 3: Effect of foliar spraying plants of garlic cultivars, with boric acid or copper sulphate as well as their interactions on chemical constituents of plant foliage during two seasons of study.

\begin{tabular}{|c|c|c|c|c|c|c|c|c|c|}
\hline \multicolumn{2}{|c|}{ Treatment } & \multicolumn{4}{|c|}{$2017 / 2018$} & \multicolumn{4}{|c|}{ 2018/2019 } \\
\hline Cultivars & Foliar spray & $\begin{array}{l}\mathbf{N} \\
\%\end{array}$ & $\begin{array}{c}\mathbf{P} \\
\%\end{array}$ & $\begin{array}{l}\mathbf{K} \\
\%\end{array}$ & $\begin{array}{c}\text { Total carbo- } \\
\text { hydrate\% }\end{array}$ & $\begin{array}{l}\mathbf{N} \\
\%\end{array}$ & $\begin{array}{c}\mathbf{P} \\
\%\end{array}$ & $\begin{array}{l}\mathbf{K} \\
\%\end{array}$ & $\begin{array}{c}\text { Total carbo- } \\
\text { hydrate } \%\end{array}$ \\
\hline Balady & & 2.55 & 0.50 & 1.70 & 14.47 & 2.63 & 0.52 & 1.74 & 15.26 \\
\hline Sids & & 2.37 & 0.45 & 1.61 & 12.70 & 2.51 & 0.48 & 1.65 & 13.59 \\
\hline Egaseed & & 2.54 & 0.54 & 1.75 & 15.27 & 2.70 & 0.54 & 1.80 & 16.24 \\
\hline LSD at $5 \%$ & & 0.14 & $\mathbf{0 . 0 3}$ & 0.02 & 0.66 & 0.04 & 0.03 & $\mathbf{0 . 0 3}$ & 0.63 \\
\hline \multirow[b]{6}{*}{ LSD at $5 \%$} & B 100ppm & 2.45 & 0.47 & 1.66 & 13.70 & 2.56 & 0.48 & 1.69 & 14.55 \\
\hline & B 200ppm & 2.48 & 0.50 & 1.69 & 14.03 & 2.60 & 0.51 & 1.74 & 14.97 \\
\hline & $\mathrm{CuSO}_{4} 1000 \mathrm{ppm}$ & 2.54 & 0.52 & 1.72 & 14.74 & 2.67 & 0.54 & 1.78 & 15.52 \\
\hline & $\mathrm{CuSO}_{4} 2000 \mathrm{ppm}$ & 2.65 & 0.55 & 1.76 & 15.50 & 2.73 & 0.57 & 1.83 & 16.41 \\
\hline & Control & 2.34 & 0.44 & 1.60 & 12.78 & 2.50 & 0.45 & 1.62 & 13.70 \\
\hline & & 0.11 & 0.03 & 0.04 & 0.88 & $\mathbf{0 . 0 3}$ & 0.02 & 0.07 & 0.56 \\
\hline \multirow{5}{*}{ Balady } & B 100ppm & 2.55 & 0.49 & 1.68 & 14.01 & 2.58 & 0.50 & 1.71 & 14.73 \\
\hline & B 200ppm & 2.57 & 0.50 & 1.70 & 14.56 & 2.61 & 0.51 & 1.75 & 15.16 \\
\hline & $\mathrm{CuSO}_{4} 1000 \mathrm{ppm}$ & 2.63 & 0.52 & 1.74 & 15.12 & 2.69 & 0.55 & 1.80 & 15.85 \\
\hline & $\mathrm{CuSO}_{4} 2000 \mathrm{ppm}$ & 2.68 & 0.55 & 1.77 & 15.83 & 2.73 & 0.58 & 1.83 & 16.64 \\
\hline & Control & 2.35 & 0.45 & 1.61 & 12.87 & 2.54 & 0.46 & 1.64 & 13.95 \\
\hline \multirow{5}{*}{ Sids } & B 100ppm & 2.33 & 0.42 & 1.58 & 12.16 & 2.48 & 0.46 & 1.61 & 13.07 \\
\hline & B 200ppm & 2.37 & 0.44 & 1.62 & 12.42 & 2.51 & 0.48 & 1.68 & 13.52 \\
\hline & $\mathrm{CuSO}_{4} 1000 \mathrm{ppm}$ & 2.43 & 0.48 & 1.65 & 13.19 & 2.55 & 0.51 & 1.70 & 13.96 \\
\hline & $\mathrm{CuSO}_{4} 2000 p p m$ & 2.50 & 0.52 & 1.68 & 13.92 & 2.63 & 0.54 & 1.74 & 14.67 \\
\hline & Control & 2.26 & 0.41 & 1.53 & 11.82 & 2.42 & 0.43 & 1.55 & 12.74 \\
\hline \multirow{5}{*}{ Egaseed } & B 100ppm & 2.48 & 0.52 & 1.72 & 14.93 & 2.64 & 0.50 & 1.75 & 15.86 \\
\hline & B 200ppm & 2.51 & 0.56 & 1.75 & 15.11 & 2.68 & 0.55 & 1.81 & 16.24 \\
\hline & $\mathrm{CuSO}_{4}$ 1000ppm & 2.56 & 0.57 & 1.79 & 15.92 & 2.79 & 0.58 & 1.86 & 16.75 \\
\hline & $\mathrm{CuSO}_{4} 2000 \mathrm{ppm}$ & 2.77 & 0.59 & 1.84 & 16.75 & 2.85 & 0.61 & 1.93 & 17.92 \\
\hline & Control & 2.42 & 0.48 & 1.67 & 13.65 & 2.56 & 0.47 & 1.69 & 14.43 \\
\hline LSD at $5 \%$ & & 0.19 & 0.05 & 0.07 & 1.53 & 0.18 & 0.03 & 0.04 & 1.05 \\
\hline
\end{tabular}

Table 4: Effect of foliar spraying plants with boric acid or copper sulphate as well as their interactions on copper, boron and Sulphur content of garlic plant foliage during two seasons of study.

\begin{tabular}{|c|c|c|c|c|c|c|c|}
\hline \multicolumn{2}{|c|}{ Treatment } & \multicolumn{3}{|c|}{$2017 / 2018$} & \multicolumn{3}{|c|}{ 2018/2019 } \\
\hline Cultivars & Foliar spray & $\begin{array}{c}\mathrm{Cu} \\
(\mathbf{p p m})\end{array}$ & $\begin{array}{c}\text { B } \\
(\mathrm{ppm})\end{array}$ & $\begin{array}{c}\mathrm{S} \\
\% \\
\%\end{array}$ & $\begin{array}{c}\mathrm{Cu} \\
(\mathbf{p p m})\end{array}$ & $\begin{array}{c}\text { B } \\
(\mathrm{ppm})\end{array}$ & $\begin{array}{l}\mathrm{S} \\
\%\end{array}$ \\
\hline Balady & & 17.30 & 67.54 & 0.75 & 19.74 & 74.92 & 0.84 \\
\hline Sids & & 16.28 & 38.24 & 0.66 & 17.94 & 43.90 & 0.72 \\
\hline Egaseed & & 18.12 & 43.84 & 0.70 & 21.80 & 50.96 & 0.78 \\
\hline LSD at $5 \%$ & & 0.72 & 2.24 & 0.03 & 1.06 & 2.30 & 0.03 \\
\hline \multirow[b]{6}{*}{ LSD at $5 \%$} & B 100ppm & 16.03 & 43.10 & 0.67 & 18.63 & 49.83 & 0.75 \\
\hline & B 200ppm & 16.70 & 49.65 & 0.70 & 19.26 & 51.06 & 0.78 \\
\hline & $\mathrm{CuSO}_{4}$ 1000ppm & 18.90 & 38.63 & 0.74 & 21.33 & 46.60 & 0.82 \\
\hline & $\mathrm{CuSO}_{4} 2000 \mathrm{ppm}$ & 21.16 & 39.43 & 0.78 & 22.86 & 47.16 & 0.86 \\
\hline & Control & 13.36 & 38.56 & 0.64 & 17.03 & 43.30 & 0.70 \\
\hline & & 1.27 & 1.32 & 0.02 & 1.15 & 1.73 & 0.04 \\
\hline \multirow{5}{*}{ Balady } & B 100ppm & 16.10 & 43.20 & 0.71 & 18.40 & 50.70 & 0.82 \\
\hline & B 200ppm & 16.70 & 48.93 & 0.75 & 18.90 & 51.30 & 0.86 \\
\hline & $\mathrm{CuSO}_{4}$ 1000ppm & 18.90 & 38.50 & 0.79 & 21.10 & 46.80 & 0.87 \\
\hline & $\mathrm{CuSO}_{4} 2000 \mathrm{ppm}$ & 21.60 & 39.70 & 0.83 & 22.80 & 47.60 & 0.92 \\
\hline & Control & 13.20 & 37.40 & 0.68 & 17.50 & 43.20 & 0.76 \\
\hline \multirow{5}{*}{ Sids } & B 100ppm & 15.20 & 39.60 & 0.62 & 16.60 & 45.90 & 0.70 \\
\hline & B 200ppm & 16.10 & 41.90 & 0.66 & 17.30 & 47.30 & 0.72 \\
\hline & $\mathrm{CuSO}_{4}$ 1000ppm & 18.60 & 35.80 & 0.71 & 19.50 & 42.90 & 0.78 \\
\hline & $\mathrm{CuSO}_{4}$ 2000ppm & 19.30 & 36.20 & 0.75 & 20.90 & 43.20 & 0.81 \\
\hline & Control & 12.20 & 37.70 & 0.59 & 15.40 & 40.20 & 0.63 \\
\hline \multirow{5}{*}{ Egaseed } & B 100ppm & 16.80 & 46.50 & 0.68 & 20.90 & 52.90 & 0.74 \\
\hline & B 200ppm & 17.30 & 48.13 & 0.70 & 21.60 & 54.60 & 0.78 \\
\hline & $\mathrm{CuSO}_{4}$ 1000ppm & 19.20 & 41.60 & 0.74 & 23.40 & 50.10 & 0.82 \\
\hline & $\mathrm{CuSO}_{4} 2000 \mathrm{ppm}$ & 22.60 & 42.40 & 0.77 & 24.90 & 50.70 & 0.86 \\
\hline & Control & 14.70 & 40.60 & 0.65 & 18.20 & 46.50 & 0.71 \\
\hline LSD at $5 \%$ & & 2.20 & 3.10 & 0.04 & 1.99 & 3.07 & 0.07 \\
\hline
\end{tabular}

Foliar sprays significantly increased all studied plant foliage constituents, i.e N, P, K, carbohydrate, and $\mathrm{S}$ percentages, $\mathrm{B}$ as well as $\mathrm{Cu}(\mathrm{ppm})$ compared to the control treatment. In this concern, spraying the garlic plants 4 times with $\mathrm{CuSo}_{4}$ at 2000ppm every 2 weeks intervals starting 30 days from planting recorded the highest increments in all studied assayed chemical compound followed by $\mathrm{CuSo}_{4}$ at $1000 \mathrm{ppm}$ and boric acid, except boron content where the foliage highest were obtained from the plant 
sprayed with boric acid at 200ppm followed by $100 \mathrm{ppm}$.as well as Obtained results are to some extent similar during both seasons of growth. Similar trends were also recorded by Choudhary et al. (2014) and Zhou et al. (2018).

As for the effect of the interaction between garlic cultivars and foliar spray treatments, the same data in Tables and, reveal that plants of Egaseed cultivar and sprayed by $\mathrm{CuSo}_{4}$ at 2000ppm as a foliar application, produced the highest significant values for nitrogen percentage as well as phosphorus, potassium, carbohydrates and copper percentage, in the two tested seasons. Whereas, the maximum significant values for sulphur and boron content were gained with Balady cultivar and foliar spray with Boric acid at $200 \mathrm{ppm}$ in the two experimental seasons. The results were true during the two seasons of study.

\section{Bulb yield and its component:}

Data presented in Table (5) clearly show that, total bulbs yield and its components expressed as plant weight, number of cloves, average head weight and total yield (ton/fed), were affected by garlic cultivars and / or the foliar application of some nutrients, i.e, boric acid and copper sulphate. However, the obtained data reveal that Egaseed cultivar recorded the highest values in all studied yield parameters except number of cloves per head which was noticed in Balady cultivar. These findings were true in both seasons.

Table 5: Effect of garlic cultivars, foliar spray with boron or copper sulphate as well as their interactions on bulb yield and its components of garlic plants (180 day from planting) during two seasons of study.

\begin{tabular}{|c|c|c|c|c|c|c|c|c|c|}
\hline \multicolumn{2}{|c|}{ Treatment } & \multicolumn{4}{|c|}{$2017 / 2018$} & \multicolumn{4}{|c|}{$2018 / 2019$} \\
\hline Cultivars & Foliar spray & $\begin{array}{c}\text { Plant } \\
\text { weight } \\
\text { (g) }\end{array}$ & $\begin{array}{c}\text { No. } \\
\text { of } \\
\text { cloves }\end{array}$ & $\begin{array}{c}\text { Average } \\
\text { head } \\
\text { weight } \\
\text { (g) }\end{array}$ & $\begin{array}{c}\text { Total } \\
\text { yield } \\
\text { (ton/fed) }\end{array}$ & $\begin{array}{c}\text { Plant } \\
\text { weight } \\
\text { (g) }\end{array}$ & $\begin{array}{c}\text { No. } \\
\text { of cloves }\end{array}$ & $\begin{array}{c}\text { Average } \\
\text { head } \\
\text { weight } \\
\text { (g) }\end{array}$ & $\begin{array}{c}\text { Total } \\
\text { yield } \\
\text { (ton/fed) }\end{array}$ \\
\hline Balady & & 441.86 & 27.06 & 96.32 & 9.500 & 431.68 & 26.93 & 90.70 & 9.587 \\
\hline Sids & & 237.96 & 16.80 & 55.90 & 5.884 & 243.98 & 16.73 & 55.16 & 5.916 \\
\hline Egaseed & & 506.13 & 23.53 & 98.62 & 11.314 & 491.93 & 22.80 & 98.67 & 11.950 \\
\hline LSD at $5 \%$ & & 22.10 & 1.85 & 5.24 & 1.143 & 52.70 & 0.99 & 21.62 & 0.521 \\
\hline \multirow[b]{6}{*}{ LSD at $5 \%$} & B 100ppm & 379.02 & 22.00 & 75.23 & 9.071 & 371.64 & 21.88 & 75.18 & 8.914 \\
\hline & B 200ppm & 376.06 & 22.22 & 83.81 & 9.134 & 390.52 & 22.00 & 82.58 & 9.187 \\
\hline & $\mathrm{CuSO}_{4}$ 1000ppm & 397.77 & 22.55 & 87.84 & 9.333 & 417.04 & 22.33 & 87.22 & 9.229 \\
\hline & $\mathrm{CuSO}_{4} 2000 \mathrm{ppm}$ & 466.01 & 22.88 & 97.50 & 9.437 & 441.56 & 22.88 & 95.92 & 9.604 \\
\hline & Control & 357.72 & 21.66 & 73.68 & 7.522 & 325.21 & 21.66 & 66.63 & 8.821 \\
\hline & & 23.25 & 1.07 & 6.71 & 1.650 & 74.01 & 1.03 & 15.93 & 0.452 \\
\hline \multirow{5}{*}{ Balady } & B 100ppm & 371.83 & 26.66 & 89.33 & 9.437 & 400.10 & 26.66 & 85.20 & 9.250 \\
\hline & B 200ppm & 382.10 & 27.00 & 96.93 & 9.500 & 465.96 & 27.00 & 97.40 & 9.500 \\
\hline & $\mathrm{CuSO}_{4}$ 1000ppm & 460.33 & 27.33 & 98.96 & 9.687 & 483.30 & 27.00 & 91.63 & 9.875 \\
\hline & $\mathrm{CuSO}_{4}$ 2000ppm & 526.36 & 27.66 & 111.86 & 9.750 & 468.86 & 27.33 & 106.63 & 10.062 \\
\hline & Control & 468.66 & 26.66 & 84.50 & 9.125 & 340.16 & 26.66 & 72.63 & 9.250 \\
\hline \multirow{5}{*}{ Sids } & B 100ppm & 231.76 & 16.66 & 44.86 & 5.715 & 230.73 & 16.33 & 48.40 & 5.867 \\
\hline & B 200ppm & 231.76 & 16.66 & 59.43 & 5.840 & 217.63 & 16.33 & 53.63 & 6.000 \\
\hline & $\mathrm{CuSO}_{4}$ 1000ppm & 191.73 & 17.00 & 61.83 & 6.062 & 267.73 & 17.33 & 61.53 & 6.110 \\
\hline & $\mathrm{CuSO}_{4}$ 2000ppm & 317.03 & 17.33 & 71.23 & 6.250 & 311.06 & 17.66 & 70.93 & 6.125 \\
\hline & Control & 217.53 & 16.33 & 42.16 & 5.160 & 192.73 & 16.00 & 41.30 & 5.590 \\
\hline \multirow{5}{*}{ Egaseed } & B 100ppm & 469.56 & 22.66 & 91.50 & 12.062 & 484.10 & 22.66 & 91.96 & 11.625 \\
\hline & B 200ppm & 514.33 & 23.00 & 95.06 & 12.062 & 487.96 & 22.66 & 96.73 & 12.062 \\
\hline & $\mathrm{CuSO}_{4}$ 1000ppm & 541.26 & 23.33 & 102.73 & 12.249 & 500.10 & 22.66 & 108.50 & 11.812 \\
\hline & $\mathrm{CuSO}_{4} 2000 \mathrm{ppm}$ & 554.63 & 26.66 & 109.40 & 12.312 & 544.76 & 23.66 & 110.20 & 12.624 \\
\hline & Control & 450.86 & 22.00 & 94.40 & 7.886 & 442.73 & 22.33 & 85.96 & 11.625 \\
\hline LSD at $5 \%$ & & 40.26 & 3.08 & 11.62 & 1.858 & 128.20 & 1.79 & 27.59 & 0.783 \\
\hline
\end{tabular}

Whereas, this superiority amounted by 506.13, 23.53, 98.62g and $11.314 \mathrm{t} /$ fed in the first season, for plant weight, number of cloves, average head weight and total yield (ton/fed), respectively. In the second season, this superior amounted by 491.93, 22.80, 98.67, 11.95 for the same above respective parameters. Such superiority of Egaseed regarding weight produced total yield and single bulb are connected with the superiority in vegetative growth Table 2 and high chemical constituents (Table) which consequently reflected on the produced yield. On the other hand, the lowest values for all bulb yield and its components were recorded with sids 40 cultivar. Obtained results were true during both seasons of study. Such differences in chemical constituents among the studied cultivars may be attributed to the potential of genetic differences among such genotypes. Obtained results are parallel 
with those reported by Akbari et al. (2017) and Hegazy et al. (2019). In this regards, Zaki et al., (2014) indicated that Sids-40 gave the heaviest total yield and biggest neck and bulb diameters compared with Balady cultivar. Also, Abd El-Rasheed et al. (2016) stated that all average fresh weight at harvest (yield/plant) of garlic plants differed among the studied genotypes. Also, the cloved genotypes showed the highest values which was highly significant in Sid 40, clone 22 and Egaseed 1, which clone 10, Egaseed clone and Alowaint showed the lowest values.

The effect of some nutrients, i.e., boric acid and copper sulphate on total bulbs yield and its components are presented in Table (3). It is obvious that, the two active materials of spraying the plants caused an enhancement in total produced bulb yield and its components expressed as plant weight, number of cloves per head, average head weight and total yield compared with the control treatment. Obtained results were nearly similar during the two seasons of study. In this connection, the highest total produced bulb yield and its components were obtained as a result of spraying garlic plants 4 times with $\mathrm{CuSO}_{4}$ at 2000ppm starting 30 days form planting date and every two weeks as intervals. In addition, treatment of $\mathrm{CuSO}_{4}$ at $1000 \mathrm{ppm}$ ranked the second followed by boron at $200 \mathrm{ppm}$ without significant difference between them. However, no significant results were recorded in number of cloves in the two tested seasons. Such increments in bulb yield (total yield) due to treating the plants with tested foliar sprays were connected with their effect on increasing the vegetative growth parameters (Table 2). In addition, it's effects on increasing macro and micro nutrients (Tables, 5 and 6 ) which affect plant growth and in turn increased its productivity. Also using such tested growth stimulants reduced percentage of the infected bulb percentage and the number of days elapsed to harvest the yield. Obtained results are in parallel to that reported by Choudhary et al.(2014) and Zhou et al.(2018) on garlic. The increase in bulb yield of garlic with the application of higher levels of sulphur might be due to enhanced synthesis and translocation of photosynthesis to the bulbs and the storage organs of the garlic which in turn might be caused by increased uptake of N, P, K and S by plant roots of crop as revealed by Shete et al. (2018) on garlic. Successive improvement in growth and yield attributing characters in garlic is due to greeted levels of application of Sulphur which increased both marketable and total bulb yields. Similar studies were done and his results coincided with the present study i.e., plant height, number of leaves, bulb diameter, number of cloves per bulb, bulb weight and bulb yield were higher in plots treated with higher S. The improvement in growth characters with the application of sulphur might be due to its role in the synthesis of chlorophyll. Sulphur is an essential plant nutrient, its role in balanced fertilization and consequently in crop production is being realized in recent times. It performs many physiological functions like synthesis of sulphur containing amino acids. Overall increase in growth attributes of crop may be due to higher availability of sulphur in the rhizosphere system of the plants which might have resulted in increased uptake of nutrients that used in photosynthesis The improvement on growth and yield of garlic might be due to the enhanced enzymatic and photosynthetic activity and the greater translocation rate due to the influence of boron. The favorable effects of boron might be attributed due to its involvement in cell division and cell expansion (Babaleshwar, et al., 2017).

With regard to the effect of the interaction treatments between garlic cultivars and foliar spray treatments on total bulb yield and it's components ,data presented in Table, 3 results show clearly that the highest total produced yield per feddan and average plant weight were in a descending order obtained as a result of spraying plant of Egaseed cv. with $\mathrm{CuSO}_{4}$ at $2000 \mathrm{ppm}$ followed by $\mathrm{CuSO}_{4}$ at $1000 \mathrm{ppm}$ and boron at 200 and $100 \mathrm{ppm}$, respectively whereas the highest number of cloves per head were obtained from the interaction treatment between Balady cultivar and foliar spray with $\mathrm{CuSO}_{4}$ at $2 \mathrm{~g} / \mathrm{l}$ followed by $\mathrm{CuSO}_{4}$ at a rate of $1 \mathrm{~g} / \mathrm{l}$ during the two seasons of growth.

\section{Bulb quality:}

Concerning the effect of cultivars on physical bulb characters, i.e., average bulb length, diameter, average clove and bulb ratio data presented in Table (6) weight, show that the tested cultivars significantly affected physical bulb characteristics. Where, the highest clove weight and bulb length and diameter were obtained by cv. Egaseed followed by Balady cultivar for length and diameter in the first season and diameter in the second one as well as Sids 40 cultivar for clove weight in the first season and clove weight and length in the second one. While, no significant differences among the three cultivars in the bulb length were detected during the two seasons of growth. Akbari et al. (2017) and Hegazy et al. (2019) reported similar results. These variations among the cultivars in latter characters could be referring to the genetic constituents which led to differences in tissues of garlic bulbs. 
Moreover, Abouziena and El-Saeid (2013) stated that Bulb of Balady cultivar had more than two folds of cloves number per bulb than the Chinese lines. On the contrary, Balady cv had the lowest clove weight compared to all Chinese lines.

Table 6: Effect of garlic cultivars, foliar spray with boron or copper sulphate as well as their interactionson physical characteristics quality of garlic bulbs during two seasons of study

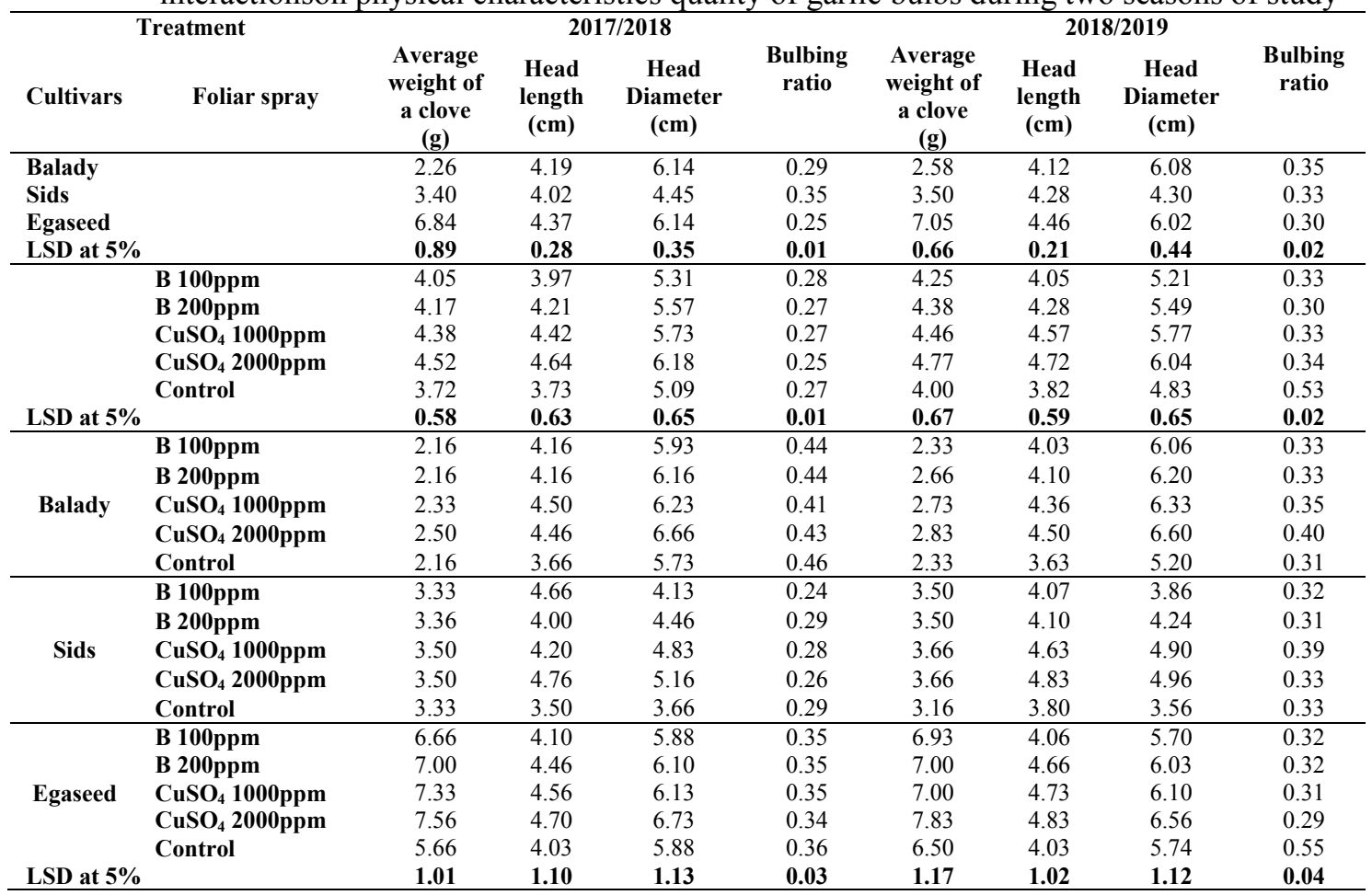

Regarding the effect of tested foliar substances (copper sulphate and boric acid) on the physical bulb quality characteristics, data reveal that foliar spray either boric acid at 100 or $200 \mathrm{ppm}$ as well as $\mathrm{CuSO}_{4}$ at 1 and $2 \mathrm{~g} / \mathrm{l}$ starting 30 days after planting and every two weeks interval significantly increased average clove weight and bulb length and diameter compared with the control treatment which was sprayed with tap water.. Moreover, in desceuding order plants sprayed by $\mathrm{CuSO}_{4}$ at $2 \mathrm{~g} / 1$ showed the highest significant values for clove weight and bulb length and diameter followed by CuSo4 at 1000ppm and boric acid at $200 \mathrm{ppm}$ and finally boric acid at $100 \mathrm{ppm}$ in both seasons of growth. Similar results were recorded by Choudhary et al., (2014) and Zhou et al., (2018). found that bulb size seems to be the most important component closely related with yield per unit aera. The favorable effects of micronutrients might be attributed due to its involvement in cell division and cell expansion, improvement of physiological activities like photosynthesis during food manufacture by the plant and then the translocation to the bulb. Also, found that bulb diameter, clove weight and number of cloves per bulb were affected by sprayed borax.

Respecting the effect of the interaction, the studied combination between cultivars and the foliar application of boric acid and copper sulphate on physical fruit quality characteristics indicated that, the highest values in all measured bulb parameters (weight, length diameter and bulb ratio) were obtained as a result of the combination between cv. Egaseed when combined with $\mathrm{CuSO}_{4}$ at $2000 \mathrm{ppm}$ as spray addition during the two seasons of growth. Whereas, the treatments using plants of Egaseed cultivars then foliar sprayed with $\mathrm{CuSo}_{4}$ at $2000 \mathrm{ppm}, \mathrm{CuSo}_{4}$ at $1000 \mathrm{ppm}$, boric acid 100 or $200 \mathrm{ppm}$ produced the highest significant values for average bulb weight in the both tested seasons. In addition, the maximum bulb length was obtained with Egaseed cultivar combined with $\mathrm{CuSO}_{4}$ at $2000 \mathrm{ppm}$ as a foliar application without significant differences among it and $\mathrm{CuSo}_{4}$ at $2000 \mathrm{ppm}, \mathrm{CuSo}_{4}$ at $1000 \mathrm{ppm}, \mathrm{B}$ at 100 and $200 \mathrm{ppm}$ as well as Balady cultivar and all foliar application treatments. However, CuSo4 at $2000 \mathrm{ppm}$ positively increased head diameter for the three cultivars in the two tested seasons. 


\section{Conclusion}

It may be concluded that garlic plants of Egaseed cultivar showed superiority and exceded in a descending order those of Balady and Sids 40 regarding vegetative growth and productivity combined with best quality. Apart from used cultivars, spraying plants four times i.e., 30, 45, 60 and 75 days from planting with boric acid at 100 or $200 \mathrm{ppm}$ or $\mathrm{CuSO} 4$ at 1000 and $2000 \mathrm{ppm}$ improved vegetative growth and yield productivity as compared with control treatment (sprayed with tap water)

Finally, under similar prevailing circumstances it can be recommended to use plants of Egassed cultivar combined with spaying such plants 4 times with $\mathrm{CuSO} 4$ at 2000ppm to gain the highest garlic yield with best cloves quality.

\section{References}

A.O.A.C., 1990. Official and tentative methods of analysis. Association of Official Analytical Chemists. Washington, D.C., U.S.A.

Abd El-Rasheed, K.G., Y. M. Moustfa, E. A. Hassan, Y. Y. Abd El-Ati and S. H. Gadel-Hak. 2016. Traits under laboratory conditions to identify garlic genotypes suitable for organic agriculture. Egypt J. Agric. Res., 94(1):73-88.

Ahmed, A.M.M., 2012. Response of garlic plant to nitrogen, phosphorus, potassium and some biofertilizer levels under sandy soil conditions. Ph.D. Thesis, Fac. Agric., Zagazig Univ.

Akbari, S., M. Kafi and S. R. Beidokhti, 2017. Effect of drought stress on growth and morphological characteristics of two garlic (Allium sativum L.) ecotypes in different planting densities. Agroecology, 9(2): 559-574

Babaleshwar, S. B., R. Shilpa, K. Koppad, K. Math and R. Dharmatti, 2017. Influence of sulphur on growth and yield of garlic (Allium sativum L.). Pharmacognosy and Phytochemistry, 6(5): 450452.

Brown, J. and O. Lilliland, 1946. Rapid determination of potassium and sodium in plant material and soil extracts by flame photometric. Proc. Amer. Soc. Hort. Sci., 48: 341- 346.

Choudhary, M. K., A. Kavita, I. B. Maurya, B. Singh, M. K. Sharma and P. K. Hatwal, 2014. Effect of biofertilizers and micronutrients on growth and yield of garlic (Allium sativum L.) var. 'G-282'. Progressive Hort., 46(2):367-371.

Gomez, K.A. and A.A. Gomez, 1984. Statistical procedures for Agricultural Research (Second E d.), pp: 457- 423. John Wiley and Sons. Inter. Sci. Pub. New York.

Hegazy, H.H., G. A. Elsharkawy and S. E. S. Ahmad, 2019. Evaluation the growth performance of Egyptian garlic landraces and in vitro synseeds of bulblets formation. Alexandria Agri. Sci., 63(6): 339-352.

Herbert, D., P.J. Phipps and R.E. Strange, 1971. Determination of total carbohydrates, Methods in Microbiology, 5 (8): 290-344.

John, M. K. 1970. Colorimetric determination of phosphorus in soil and plant material with ascorbic acid. Soil Sci., 109:214-220

Lenkova, M., J. Bystricka, P. Chlebo J. and Kovarovic, 2018. Garlic (Allium sativum L.) the content of bioactive compounds. Potravinarstvo: Slovak J. of Food Sci., 12(1):405-412.

Mann, L. K. 1952. Anatomy of the garlic bulb and factors affecting bulb development. Hilgardia, 21: 195-228.

Manna, D., T.K.M. Aity and A. Ghosal, 2014. Influence of foliar application of boron and zinc on growth, yield and bulb quality on onion. J. Crop Weed, 10 (1): $53-55$.

Pregl, E., 1945. Quantitative organic micro analysis. $4^{\text {th }}$ Ed. J. Chundril, London.

Rizk, F.A., A.M. Shaheen, E.H. Abd El- Samad and T.T. El- Labban, 2014. Response of onion plants to organic fertilizer and foliar spraying of some micronutrients under sandy soil condition. J. Applied Sci. Res., 10 (5): 383 - 392.

Shete, M. B., H. M. Chiktey, S. B. Jadhav and M. N. Bhalekar, 2018. Effect of sulphur on growth, yield and quality of garlic (Allium sativum L.). Int. J. Chemical Studies; 6(1):552-555.

Zaki, H.E.M., H.S. Tony and R. M. Abd-Elraouf, 2014. Response of two garlic cultivars (Allium sativum) to inorganic and organic fertilization. Nat. Sci., 12(10):52-60. 
Zhang, T. L., S. Q. ShiQi, X. W. Chen, Y. Y. Liu and X. H. Song, 2012. Effects of boron on the formation of onion-type garlic and its change of physiological characteristics. Acta Hort. Sci., 39(1):109-118.

Zhou, L. J., X. D. Sun and S. Q. Liu, 2018. Effect of applying sulfur and silicon combination on growth, photosynthetic characteristics and quality of garlic seedling by hydroponic culture. China Vegetables; (11):45-48. 